\title{
Islamic Psycho-Spiritual Support Model for Disaster Victims
}

\author{
Rafeah Saidon'1, Siti Khadijah Ab Manan'1, \\ Rosilawati Sueb², Fairuz Nazri Abd Rahman ${ }^{3}$
}

\author{
${ }^{1}$ Academy of Contemporary Islamic Studies (ACIS), Universiti Teknologi MARA Shah Alam, 40450 Shah Alam, Selangor Malaysia \\ ${ }^{2}$ Faculty of Education, Universiti Teknologi MARA Shah Alam, 40450 Shah Alam, Selangor Malaysia \\ ${ }^{3}$ Psychiatry Department, Universiti Kebangsaan Malaysia (UKM), 56000, Cheras, Kuala Lumpur, Malaysia
}

rafeahs@uitm.edu.my, sitik274@salam.uitm.edu.my, rosila334@uitm.edu.my, fairuzn@ppukm.ukm.edu.my

Tel of $1^{\text {st }}$ Author: 017-2242724

\begin{abstract}
Religiosity and spiritual experiences are primarily associated with better physical and mental health, less need for health services, faster recovery from illness, and increased longevity. Unfortunately, in any disasters or calamities, psycho-spiritual consequences are given less emphasis. In fact, to date, there has been no specific and comprehensive religious-based model being introduced to the victims in minimizing the risks of psycho-spiritual impacts. Therefore, the objective of this study is to describe a proposed model of psycho-spiritual support for disaster victims based on the Islamic principles of maqasid shariah.
\end{abstract}

Keywords: Islamic; psycho-spiritual; model; disaster

eISSN: 2398-4287 (C) 2021. The Authors. Published for AMER ABRA cE-Bs by e-International Publishing House, Ltd., UK. This is an open access article under the CC BYNC-ND license (http://creativecommons.org/licenses/by-nc-nd/4.0/). Peer-review under responsibility of AMER (Association of Malaysian Environment-Behaviour Researchers), ABRA (Association of Behavioural Researchers on Asians) and cE-Bs (Centre for Environment-Behaviour Studies), Faculty of Architecture, Planning \& Surveying, Universiti Teknologi MARA, Malaysia. DOI: https://doi.org/10.21834/ebpj.v6iSI5.2932

\subsection{Introduction}

Within these past decades, natural and human-caused disasters that occur globally had affected many individuals. In the case of Malaysia, a natural disaster in the form of floods, landslides, haze, and the occasional mild earthquake had inflicted quite a significant number of victims. Yearly, floods are reported as the most frequent hazard that caused extensive damage, which had attributed to a considerable amount of human lives lost, disease epidemics, property and crop damage, and other losses. Within two decades, 1998 2018, Malaysia has experienced 51 natural disasters, and as a result, more than 3 million people were affected, 281 people died, and as a whole, due to the disasters, Malaysia suffers nearly US\$2 billion (MYR8 billion) in damages (Malaysia: Disaster Management Reference Handbook, 2019).

The after-effect of the natural disasters left some victims to lose their loved ones, suffered an injury, loss of livestock, property damage, and economic loss. (Statista Research Department, 2019). Some victims were able to cope with the situation reasonably well, but many were not. They succumbed to emotional and physical health problems. According to Shultz, Yuval, Allen, and Espinel (2013), in their research article, Psychological Impacts of Natural Disasters, the consequence of psychological impacts is explained across four elements which are scope, severity, duration, and disaster type. The first element, which is scope states that psychosocial effects are wide-ranging and pervasive, and more victims are affected psychologically than are physical. Survivors might experience more difficulties in post-impact disaster rather than the event itself. Post impact hardships are experienced by some survivors as more complicated than the disaster event itself. Mental health issues usually persist longer despite the fading of physical threats in the process.

eISSN: 2398-4287 @ 2021. The Authors. Published for AMER ABRA cE-Bs by e-International Publishing House, Ltd., UK. This is an open access article under the CC BYNC-ND license (http://creativecommons.org/licenses/by-nc-nd/4.0/). Peer-review under responsibility of AMER (Association of Malaysian Environment-Behaviour Researchers), ABRA (Association of Behavioural Researchers on Asians) and cE-Bs (Centre for Environment-Behaviour Studies), Faculty of Architecture, Planning \& Surveying, Universiti Teknologi MARA, Malaysia.

DOI: https://doi.org/10.21834/ebpj.v6iSI5.2932 
Some survivors use various coping strategies that are more psychological, while others may resort to physical approaches. Nevertheless, many types of research also have shown that the incorporation of religion and spirituality within the clinical practice has demonstrated significant positive impacts (Adhikari, 2019; Sabry \& Vohra, 2013). For instance, a therapy that incorporates spiritually modified cognitive elements in dealing with patients with anxiety and depression showed faster results as compared to conventional treatment without the Islamic beliefs and practices (Azhar \& Varma, 2000). In another study that involved schizophrenia patients in Saudi Arabia, results showed that by using spiritually modified cognitive therapy, the patients showed either similar or superior results compared to traditional cognitive therapy (Wahass \& Kent, 1997). These evidences indicate the significance of incorporating Islamic knowledge in the treatment of psychological issues. Therefore, with the current increase of natural disaster phenomenon globally and as well as in Malaysia, it is imperative to come out with a model of psycho-spiritual support and thus, the objective of this study is to propose a model of psycho-spiritual support for disaster victims based on the Islamic principles of maqasid shariah.

\subsection{Literature Review}

Spirituality refers to an individual's or a group's relationship with the transcendent, however that may be construed. Spirituality is about the search for transcendent meaning. Most people express their spirituality in religious practice. Others express their spirituality exclusively in their relationships with nature, music, the arts, or a set of philosophical beliefs or relationships with friends and family (Daniel P. Sulmasy, 2002). Psycho-spiritual wellbeing is a subjective experience that incorporates both emotional health and meaningin-life. It includes self-awareness, coping and adjusting effectively with stress, having satisfying relationships and connectedness with others, a sense of faith, a sense of empowerment and confidence, and living with meaning and hope (Hung \& Susan, 2003).

Preserving the psycho-spiritual wellbeing of any disaster victims is essential as the absence may lead to a distrust of God (Michael, 2008). World Health Organization (WHO) has a policy on mental health and psychosocial support to disaster victims, which should be in the form of community-based and culturally appropriate and take into account the needs of particular groups such as children, women, the elderly, etc. WHO recommends for community-based workers or trained volunteers to offer psychosocial support as they understand the needs of victims. (Conference, Aspects, \& Disaster, 2018) Besides, WHO also plays a vital role in defining the psychosocial and mental health needs of the community. The role of WHO extends in providing technical guidelines and technical support to governments, NGOs, and other stakeholders involved.

Psycho-spiritual therapy (PST) is an approach that incorporates religion and spirituality into psychotherapy. For centuries, this has been done in many settings, and across different faiths. Bhagavad Gita's concept of a mentally healthy person focuses itself on specific unique characteristics in the personality development of an average Indian which is the key to its psychotherapeutic context (Balodhi JP, Keshavan MS, 2011) Another example is Taoistic cognitive psychotherapy, which is based on the Taoist philosophy of life and health (Xiao S, Derson Y, Honggen Z,1998). Apart from that, Islamic Psychospiritual Therapy has roots well embedded in the spiritual foundation of the Qur'an and the Sunnah of the Prophet Muhammad [S.A.W], in which it is a healing technique where the individual is transferred from the realm of ill health to the field of wellbeing in a manner that is Godly (Shaharom MH, 2014). All religions view morality as a set of objective truth. When religious people commit to a specific moral regulation and standard, it will bring about positive behavior, including in terms of health (Shariff A, 2015). Psycho-spiritual therapy (PST) has been recognized for its importance in helping patients cope with various kinds of mental illnesses. A study done among 387 university students have shown that higher religious attitude correlated with lower depression score (Nazrin Asyraf Adeeb M and Rafidah Bahari, 2017)

The mental and psychological state of the victims would be able to give an idea of the kind of intervention techniques or approaches to use. Post-flood in Johor indicated preparation in both physical and psychological is a crucial aspect to be looked into. Besides, strong social support from people who are equipped with knowledge and skills on managing the victim from stress, anxiety, post-traumatic stress disorder (PTSD) and other problems relating to the effects of a natural disaster (R. Nasir, A.Z. Zainah \& R. Khairudin, 2012) is the essential aspect. Psychological preparedness is critical factors needed to oversee and adapt individual reactions before and during a disaster, Present study reveals that psychological preparation is not the same as physical readiness since it is identified as an intraindividual and mental condition of mindfulness, expectation, and availability (Waqi Suhaimi, Ahmad Marzuki, 2016).

Spiritual and inwardly reflective practices can be adopted in support of non-violent action, either alone or in groups. Prayer and meditation type of activities can provide reassurance and express solidarity (Moore, 2014). The literature suggests that a psycho-spiritual support model based on the Islamic domain that attends to their spiritual needs, religious, and mental wellbeing of victims should be as well other areas may ease the burdensome of disasters victim emotional, physical, and mentally.

\subsection{Methodology}

This study employs qualitative research as a research methodology. The method of data collection was by using a semi-structured interview whereby research would be able to obtain in-depth information regarding the topic researched. Before that, library research was conducted to examine the guiding principles relating to psycho-spiritual support based on the primary sources of Islam and the writings of contemporary scholars. This is important to understand the application of Islamic values in the psycho-spiritual support system.

Semi-structured interviews were carried out with agencies that directly involved in disaster management in Malaysia. The agency involved is the Welfare Department of Malaysia (popularly known as Jabatan Kebajikan Masyarakat or JKM). These interviews were essential for us to understand the actual practice of managing disaster victims. Besides, an academician who had conducted studies in the psycho-spiritual area was also interviewed to get feedback on the model to be proposed. 


\subsection{Results and Discussion}

In general, this study aimed at developing a model of psycho-spiritual support for disaster victims in light of the maqasid al-shariah. As already mentioned, the maqasid al-shariah (objectives of shariah) generally aim to preserve the wellbeing of the people by safeguarding the five essential qualities of life (dharuriyyah al-khams). The five qualities of life include the deen (hifz al-deen), the life (hifz al-nafs), the intellect (hifz al-aql), the dignity (hifz al-ird) and the property (hifz al-maal). The figure below is the proposed model of psycho-spiritual support based on the maqasid al-shariah.

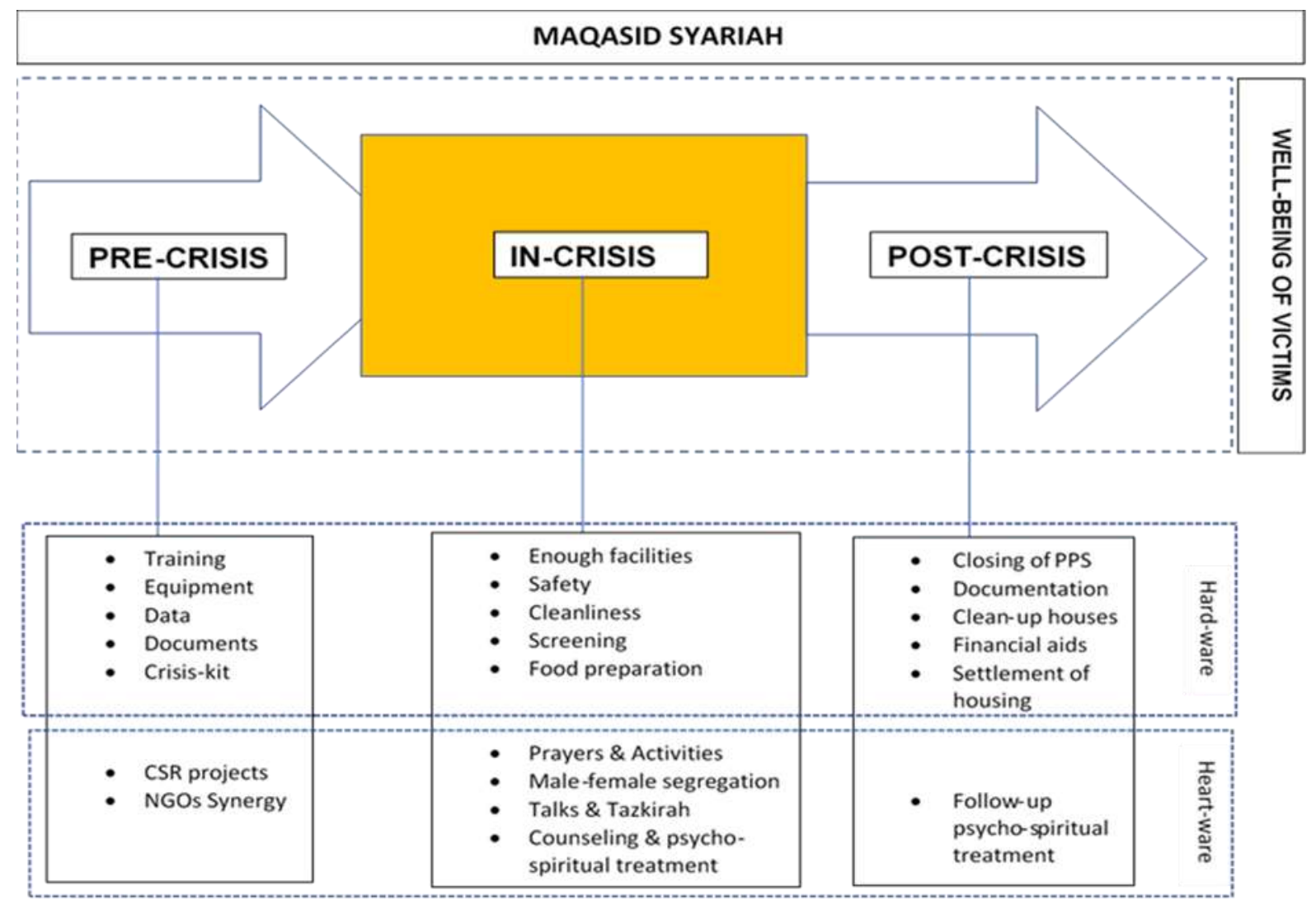

Fig 1. Psycho-spiritual Support Model

Based on the model, it is proposed that the psycho-spiritual support shall include the entire states of disaster comprising of the precrisis state, in-crisis state and the post-crisis state. The following discussions explain each of the states.

\subsection{Pre-crisis}

Crisis management as stated in the proposed model starts with the pre- crisis phase. The pre-crisis stage is more concerned with the prevention and preparation. It is to be noted that preparation in pre-crisis is very important to build individual resilience to disaster. The potential victims should learn more about the potential risks they may face, and importantly, to discover actions they can take individually and collectively to better prepare, respond, recover, and mitigate. This can be done through the awareness programs, education, guidance and advice on the dangers of disaster. For that the Department of Information and Broadcasting Department shall be mobilized for this purpose. However, for the psycho-spiritual aspects, early education relating to it is very important to strengthen the emotion, and spiritual aspect of the victims. Similarly, those who are involve in humanitarian assistance among NGO's, government agencies and individuals should be well-prepared in both aspect hard and software in managing the crisis.

Based on the proposed model, the first thing should be observed during pre-crisis is training. Members of the related team should be recruited and trained with basic disaster response skills to prepare them in assisting the community during disasters. In order to fulfil the heart ware requirement, they should also equip themselves with basic knowledge on mental health and psycho-spiritual responses to disasters.

Another important aspect for pre- crisis is an effective coordination. Disaster preparedness requires a multi-disciplinary, all-hazards approach to addressing the issues involved, and collaboration among government and non-government organizations (NGOs), research and training institutions, and the private sector. Disaster preparedness activities should be the responsibility of government and community-based organization and integrated into development planning. Thus, all agencies involved such as police, fire departments, public health, civil defence and other organizations have to react not only efficiently and individually, but also in a coordinated manner. This is done in order to cope with any disasters in a fast and highly coordinated manner (Azizul, H. Y, Wan Norbaini, W.N., Sara Chinnasamy, 2019). 


\subsection{In-Crisis State}

The in-crisis state here refers to the period where the victims are still in the state of shock, grieve and sorrow as a result of disaster that struck their property. They might have lost their house, their vehicle, their important documents and other precious belongings. The grievances might be even worse if some of the victims lose their family members or their next-of-kin that they loved. Hence, proper handlings and treatments are needed for the victims to be assisted materially, emotionally, physically and spiritually while they are staying at the temporary placement centre (simply known as PPS or Pusat Penempatan Sementara). This is particularly applicable in the case of flood victims.

At present, many related government agencies as well as non-government organizations (NGOs) are putting their hands in assisting the victims. In searching and rescuing the victims, the related government agencies include Fire and rescue Department of Malaysia (JBPM), Malaysian Armed Forces or (ATM), Special Malaysia Disaster Assistance and Rescue Team (SMART) and Malaysia Civil Defence Force (JPA3). Paramedic teams are on duty in case of injured victims that need urgent treatment.

Once the victims are in PPS, other agencies and NGOs are managing their temporary settlement and organizing activities to keep them occupied. Among the related agencies are Welfare Department of Malaysia (JKM), Emergency Medical Services, RELA, Malaysia Civil Defence Force (JPA3) and Malaysia Red Crescent (PBSM). Ambulances are making a standby in case of emergency. Many NGOs are also assisting the government agencies by offering services in the forms of activities apart from giving away foods and other necessities. Among the NGOs are i-bantu of IKRAM, Islamic Relief Malaysia (IRM), the 3rd Force and many more. Based on interviews with JKM, among the things that they usually do in managing and entertaining the victims are:

- Making the PPS ready for temporary settlement of the victims. They work closely with other agencies such as RELA, JPA3 and others.

- Documenting the whole victims in a particular PPS by recording their names, family members and other necessary details.

- $\quad$ Giving away foods and other necessities such blanket, comforter, pillow, clothing etc.

- $\quad$ Prepare foods to the victims and volunteers.

- Making a psycho-screening to the victims by asking them to fill in a necessary screening form/instrument.

- Giving counselling and intervention to those who are badly affected by the disaster. To serve such purpose, registered counsellors are placed on duty at the PPS to cater for the need of such services. They even have a specific module in handling crisis intervention for their reference.

- $\quad$ Organizing activities to the victims such as talks, drawing and painting for kids and other related activities.

The current practice of the related agencies in handling and managing is commendable. Nevertheless, some improvement might be necessary to enhance the well-being of the victims. This study proposed for the following:

- Clear-cut segregation between males and females in the PPS. Having a separate female space is important for them to preserve their aurah apart from getting the comfort of resting or sleeping freely.

- More religious activities should be held to the victims. Activities such as congregated prayer (solat jamaah), sermon (tazkirah) and daily ma'thur zikr (ma'thurat) should be organized to the Muslims. If the number of non-Muslims is significant, similar activities based on their religious belief should be organized.

- $\quad$ Psycho-spiritual therapy (PST) should also be introduced as a form of psychological intervention to those victims who are in deep crisis. PST is a module developed by a group of researchers in University of Malaya. Based on our interview with the researchers, it is proposed for the PST to be included in intervening the victims who are suffering psychologically Many studies (such as Nazrin \& Rafidah, 2017; Che Zarrina et al., 2018; Zuraida et al., 2019) proved that PST is effective in treating psychologically ill patients. In this regard, a specific module for psycho-spiritual therapy based on tasawuf being developed by university researchers (Che Zarrina et al., 2013; Che Zarina et al., 2018; Zuraida et al., 2019) may become a good intervention for better recovery of the victims. They model that they developed has 10 modules to be held in at least 10 sessions. Hence, there is possibility for the modules to continue after the victims are back to their houses.

\subsection{Post-Crisis}

Post-crisis state might be even traumatic to some of the victims whenever they see the actual damage and the amount of loss that they suffer. In the case of flood, some victims might still have their houses intact and the only things need to be done is cleaning the houses and restore them back to normal. Some might have their houses partly damaged and need to be repaired apart from cleaning them. The worst is when the victims loses the whole house. This is especially true in the case of those having their houses very close to river banks, where the houses were swept away by logs and debris overflowing from the upstream. In this regard, as suggested by Ali et al. (2008), this study proposed for the victims to be provided with (i) temporary shelter that would accommodate them for 1 to 2 years while waiting for their house to be repaired or reconstructed, (ii) Permanent shelter to those who have lost their house entirely, and this could be by way of reconstructing their house in the same location or relocate to much safer areas. For those victims who still have their houses intact, they might need financial and non-financial aids to clean their houses and repair for damages. They might also need replacement for the damaged utensils and appliances. Therefore, government and non-government agencies should be mobilised and coordinated for them to get fair assistance.

As mentioned above, the suggested psycho-spiritual therapy may take longer to complete until the victims have fully recovered or at least stable. Hence, continuation of the therapy is needed for them to regain their psychological stability and spiritual enlightenment.

\subsection{Conclusion}

Despite the advances of modern Western psychology and the development of therapies that do help many patients, one area that is always overlooked is that of the human spirit and spirituality. Previous studies indicate that there is an absence of support system which comprehensively adopts psycho-spiritual support from the Islamic point of view for disaster victims. It is crucial to incorporate religious and psycho-spiritual elements in the structured model used for treating disaster victims. Both elements can produce positive desired 
effects. Thus, this study proposes the Islamic psycho-spiritual support system based on maqasid shariah (objectives of Islamic law) in which the primary concern is the protection and advancement of the five essentials namely of religion, life, family, intellect and property. In Islamic principle, the realisation of these essentials is very important for the community both collectively and individually. The suggested psycho-spiritual support includes the entire phase of disaster comprising of the pre-crisis state, in-crisis state and the postcrisis state and essentially it covers both preparation in relation to hard-ware and heart-ware. It is submitted that the formulation of Islamic for psychosocial support model is timely as it provides an alternative healing method particularly for Muslims. The model could guide victims on the correct way of dealing with any calamities according to Islam.

\section{Acknowledgment}

This work was supported in part by Malaysian Ministry of Education and Universiti Teknologi MARA (UiTM) under Grant No. (REF: 600IRMI/FRGS 5/3 (001/2017).

\section{References}

Ali Javan Forouzandeh, Mahmood Hosseini \& Maryam Sadeghzadeh. (2008). Guidelines for design of temporary shelters after earthquakes based on community participation. Paper presented at the 14th World Conference on Earthquake Engineering October 12-17, 2008, Beijing, China.

Che Zarrina Sa'ari, Sharifah Basirah Binti Syed Muhsin (2013). Cadangan Kaedah Psikoterapi Islam Berasaskan Tazkiyah al-nafs Terhadap Pembangunan Rohani Remaja Kesan dari Penyebaran Maklumat di Era Globalisasi. Jurnal Usuluddin 36, 49-74.

Che Zarrina Saari, Sharifah Basirah Syed Muhsin, \& Mohd Manawi Mohd Akib. (2018). Konsep Taubat Abu Talib al-Makki dalam Pembangunan Psikologi Diri (Abu Talib Al-Makki's Repentance Concept in Self Development Psychology). International Journal of Sufism (Qalbu Journal). 5(4), 100- 123.

Conference, W. H. O., Aspects, H., \& Disaster, T. (2018). Humanitarian Health Action Purpose Submit Date: 10.07.2018, Acceptance Date: 22.08.2018, DOI NO $10.7456 / 1080 S S E / 174$

Daniel P. Sulmasy, A Biopsychosocial-Spiritual Model for the Care of Patients at the End of Life , The Gerontologist 2002 ,Vol. 42, Special Issue III, 24-33

Hung-Ru Lin \& Susan M. Bauer-Wu (2003). Psycho-spiritual well-being in patients with advanced cancer: an integrative review of the literature Religion, Spirituality and Health: Research and Clinical Application. Integrative Literature Reviews And Meta-Analyses. Blackwell Publishing Ltd

Malaysia: Disaster Management Reference Handbook (June 2019) https://reliefweb.int/report/malaysia/malaysia-disaster-management-reference-handbook-june-2019

Michael Galea (2008). The Impact of Child Abuse on the Psycho-Spiritual and Religious Status of Maltese College Students. Pastoral Psychology (2008) 57,147-159 (Sarah, et al. (2012).

Moore, L.V. (2014). Working in Conflict: A Faith Based Toolkit for Islamic Relief. Retrieved from www.islamic-relief.org

Nazrin Asyraf Adeeb \& Rafidah Bahari. (2017). The Effectiveness of Psycho-spiritual Therapy among Mentally III Patients. J Depress Anxiety 2017, 6:2. DOI: $10.4172 / 2167-1044.1000267$

Nazrin Asyraf Adeeb M and Rafidah Bahari, The Effectiveness of Psycho-spiritual Therapy among Mentally III Patients, Adeeb and Bahari. J Depress Anxiety 2017, 6:2

R. Nasir, A.Z. Zainah \& R. Khairudin, (2012). Psycholoical Effectss on Victims of the Johor Flood 2006/2007, Asian Social Science, 8(8), 126-133, doi: 10.5539/ass.v8n8p126.

Sabry, W.M. \& Vohra, A. (2013). Role of Islam in the management of Psychiatric disorders. Indian J Psychiatry. 55(Suppl 2):205-S214.doi: 10.4103/0019-5545.105534.

Shaharom MH (2014) Islamic Psycho-Spiritual Therapy (PST): Panacea for the Drug dependent. FIMA: 155-160.

Shariff A (2015) Does religion increase moral behavior? Current Opinion in Psychology 6: 108-113.

Shultz, M. , Neria, Y. , Allen, A. \& Zelde Espine, Z. Psychological impacts of natural disasters. James 1 University of Miami Miller School of Medicine, Clinical Research Building Suite 1512, Miami, FL, USA 2 Columbia University, New York State Psychiatric Institute, New York, NY, USA 3 Barry University, Miami Shores, FL, USA

Statista Research Department (2019). https://www.statista.com/topics/2155/natural-disasters/ .

Suhaimi, A. W. \& Marzuki, N. A. (2016). The Importance of Psychological Preparedness among Flood Victims, The European Proceedings of Social \& Behavioural Sciences, 157-162).

Suresh Sundram, et. al, (2008), Psychosocial responses to disaster: An Asian perspective. Asian Journal of Psychiatry 1. Elsevier publication, 7-14.

Wahass ,S. \& Kent,G. (1997). Coping with auditory hallucinations: a cross-cultural comparison between western (British) and non-western (Saudi Arabian) patients. Balodhi JP, Keshavan MS (2011) Bhagavadgita and psychotherapy. Asian Journal of Psychiatry 4: 300-302.

Waqi Suhaimi, A., Ahmad Marzuki, N., \& Author, C. (2016). The Importance of Psychological Preparedness among Flood Victims. The European Proceedings of Social \& Behavioural Sciences, 158-168. https://doi.org/10.15405/epsbs.2016.08.23

WHO (2011). War Trauma Foundation and World Vision International, Psychological First Aid: Guide for field workers, WHO, Geneva. 
Xiao S, Derson Y, Honggen Z (1998) Taoistic cognitive psychotherapy Taoistic patients cognitive psychotherapy for A preliminary clinical trial neuro tic

Zuraida Ahmad Sabki, Che Zarrina Sa'ar, Sharifah Basirah Syed Muhsin, Goh Lei Kheng, Ahmad Hatim Sulaiman, \& Harold G Koenig. (2019). Islamic Integrated Cognitive Behavior Therapy: A Shari'ahCompliant Intervention for Muslims with Depression. Malaysian Journal of Psychiatry. 28 (1)

Azhar M.Z. \& Varma, S.L. Mental illness in the Islamic world. New York: International Universities Press; 2000. Mental illness and its treatment in Malaysia; pp. 163-85. 